\title{
Reader-centered Approach: Investigating Literary Reading Performance Profile of Students from Non-Literature Study Program
}

\author{
Thohiriyah $^{1}$, Rahayu Puji Haryanti ${ }^{2}$, Lintang Prahita Ningarum ${ }^{3}$ \\ \{thohiriyah@mail.unnes.ac.id ${ }^{1}$, rahayu_ph@mail.unnes.ac.id ${ }^{2}$, \\ lintangprahita@students.unnes.ac.id $\left.{ }^{3}\right\}$ \\ English Department, Language and Art Faculty, Universitas Negeri Semarang ${ }^{1,2,3}$
}

\begin{abstract}
Reading literary works can be frustrating, especially for non-literature students due to a certain extent. Linguistic features, styles, symbolism, and implicit expression are some predominant factors which cause ambiguity and lead to confusion to the readers. Hence, the readers tend to be more passive as they do not know what to do with the text. This fact is then the primary justification for the lecturers to minimize the demand for literary reading subjects, focusing solely on comprehension rather than appreciation. Thus, the idea of employing a reader-centered approach is aimed at helping the students of the non-literature study program to appreciate the literary works by upholding their participation as the readers of the meaning-making process. The result shows that the students of the non-literature study program can actively appreciate the literary works better. In addition, the students' performance of reading literary works shows that they can understand the literary works through the interaction between the readers and the texts.
\end{abstract}

Keywords: Reader-centered, literary reading, meaning, non-literature students

\section{Introduction}

Reading literary texts in the context of second language (L2) learning is, according to Iida and Atsushi, not as popular as it is in first language (L1) learning [5]. In Indonesia, the trend of studying language and literature is conducted separately in which English language learning often focused on language mastery using nonliterature learning media. In other words, the nature of language learning and literature learning are different concepts. In Indonesia, teaching literature gets less appreciation compared to English language teaching [9]. Low appreciation of the text is due to the fact that literature is assumed as less important than language learning, especially in non-English speaking countries or countries in which the citizen speak EFL, such as Indonesia. In addition, Indonesian people are pessimistic regarding the career opportunity for those who graduated majoring in literature. Those aforementioned facts 
trigger the teachers in an educational institution to put aside works of literature as teaching media to assist the students in learning English.

Language and literature must not be separated in the context of teaching the English language as the employment of literary texts contribute significantly to improve students' cultural awareness, linguistic knowledge, and communication competence. In addition, literary texts stimulate students' critical thinking, encourage students' selfdiscovery, and motivate students to be active readers. Furthermore, literary texts can be utilized to develop and improve reading skills and vocabularies [2], [3], [5]. In other words, literary texts and literary reading is aimed for empowering the readers.

Reading literary texts needs a certain strategy as reading literary texts has its own difficulty compared to reading a textbook as literary works are full of implied meaning reflected by the use of hyperbole, simile, et. In the context of teaching "literary reading," teachers or lecturers are supposed to provide students with a space to meet their needs dealing with developments, preferences, and interests through understanding and appreciating literary texts. Understanding and appreciating literary texts, in fact, need strategies, especially for students of a non-literature study program. This study is aimed at examining the literary reading performance profile of a nonliterature study program.

There are some factors that cause students' negative perception of literary reading based on some previous studies. The major factors are teaching avenue and choosing the reading materials. Research conducted by Hugo S Sanchez [11] reveals that a language teacher doesn't teach in a relaxed and casual way. The teachers tend to forget the essence of literary reading implication for language learning, and he argues that literary reading should be interrelated to the motivation instruments of students to learn vocabularies or text analysis. Literary reading, he asserts, should be taught in a fun way. As the teachers seem not to allow the students to free themselves from the textbook framework, the teachers put the literary reading subject to be boring and widespreading dislike.

With regard to "choosing reading materials" Nita Novianti [9] states that choosing the proper materials for reading literary texts is important. There are at least three points being emphasized by Novianti Nita [9] to be the consideration for choosing the literary text materials. They are 1) reading habit, 2) English proficiency, and 3) resources. The teachers should pay attention to the text's length, content, diction, literary text category, such as resources whether the text is classic or popular.

The previous study conducted by Hugo S Sanchez [11] emphasizes the teaching avenue that teaching literary reading should be in a fun way. However, he does not justify why teaching literary reading in a fun way has a significant impact on the students. On the other hand, Novianti Nita [9] highlights that students' habit of reading literature also influences the performance of students' reading. However, she mentions that the length of the text intimidates the students. In this case, it can be questioned whether or not reading habit or text length is the major factor causing students' low performance of literary reading.

Regarding the concept of the reader-centered approach, this approach refers to a reader response paradigm. Reader response allows the students to interact among the texts and the readers without neglecting the existence of the readers. Reader response concepts mainly concern text exploration in which the readers can relate their experience during the process of appreciating the literary texts. Rosenblatt emphasizes 
that during the reading process, readers and texts have interaction in which the readers can give meaning towards the literary text by completing the gap between knowledge and "individual disposition" [6], [10]. By doing so, the readers will not only be able to give meaning to the texts, but they also can interpret the meaning [4].

Reader response is formulated as a response to a new criticism in which it focuses on the text. New criticism underlines that the possible actor giving meaning toward the text is only the text itself [8]. Reader response, in this case, uses a paradigm that focuses on the transactional model. Reading is a transaction which involves certain readers, book page, a certain time, and context [10]. Reader response, in other words, highlights that our meaning is not merely created by the text or solely by the reader, but the meaning is created by both. The readers' position in reading literary text using the reader response paradigm actually depends on their purpose, whether they would like to position themselves as an aesthetic reader or other categories - escapist, realist. Rosenblatt (2007) states that in the transaction process between the readers and the texts, the readers will be selective in bringing certain aspects to select text elements which become their concerns, while they disregard some other elements which are not being their concerns.

With respect to literary reading, Grabe asserts that there is an interaction between the text and the readers in forming a meaning of the text [1]. Appreciating literary text by giving meaning to the text is an apparently complicated process, and it requires sufficient skills to be able to appreciate the literary texts. Reading literary texts involves a projection creation in which the readers are demanded to envision the story they are reading in the literary text. Related to the literary text appreciation, the reading comprehension process is important as the initial step before appreciating the literary texts [7].

There are, in fact, various challenges experienced by the students while reading the literary texts. Those challenges are as follows:

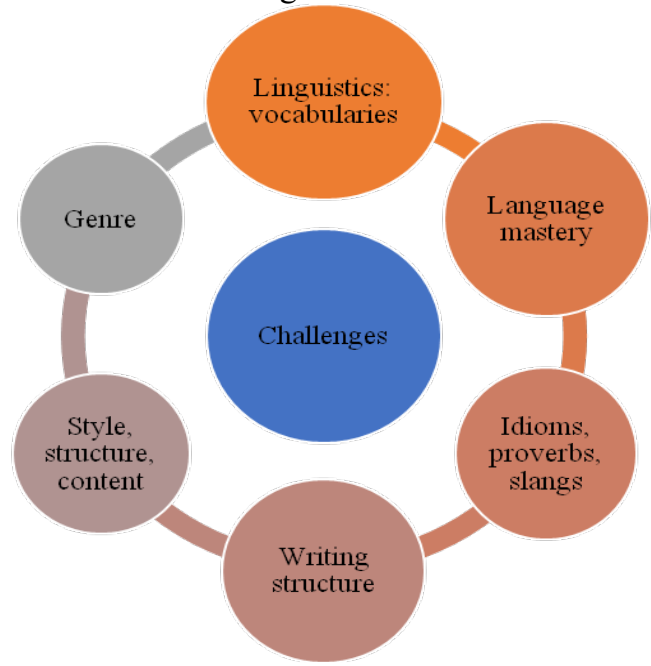

Fig. 1. Some challenges faced by the students during the reading process 
There are at least six dimensions causing difficulties in reading literary texts. They are linguistic aspects such as vocabulary, language mastery, idioms/proverbs/slangs, writing structure, style/content, and genre.

\section{Methodology}

The study involved 64 readers that are all students of the non-literature study program, English Department, joining the "literary reading" class. In order to examine the readers' performance in reading literary texts, a reader-centered approach is used. A qualitative method for this study refers to the reader-response adopted from Rosenblatt (1995) and Iser (1974), which focuses on readers' appreciation of the literary texts.

The first step is pre-reading activity in which the students will be given some pictures and visual illustrations that relate to the text they are reading to make them guess what the story is about. The second step is understanding the literary text. This step is done by giving the readers some prompts to make them comprehend the texts. Finally, after comprehending the story well, they are encouraged to appreciate the literary texts by constructing meaning for the texts.

\section{Results and Discussions \\ 3.1 The readers' profile}

The readers are 64 students of a non-literature study program joining a literary reading class in the $4^{\text {th }}$ semester. $68 \%$ of students confirmed they had experienced joining literary class, while $32 \%$ were newbies. However, they disclosed that they only once joined a literary class that was an "Introduction to Literary Studies" class when they were freshmen. The "Introduction of Literary Studies" class is aimed at giving the students a brief introduction dealing with literary texts, and reading the text is merely for entertainment. The students are not demanded to appreciate and interpret the texts.

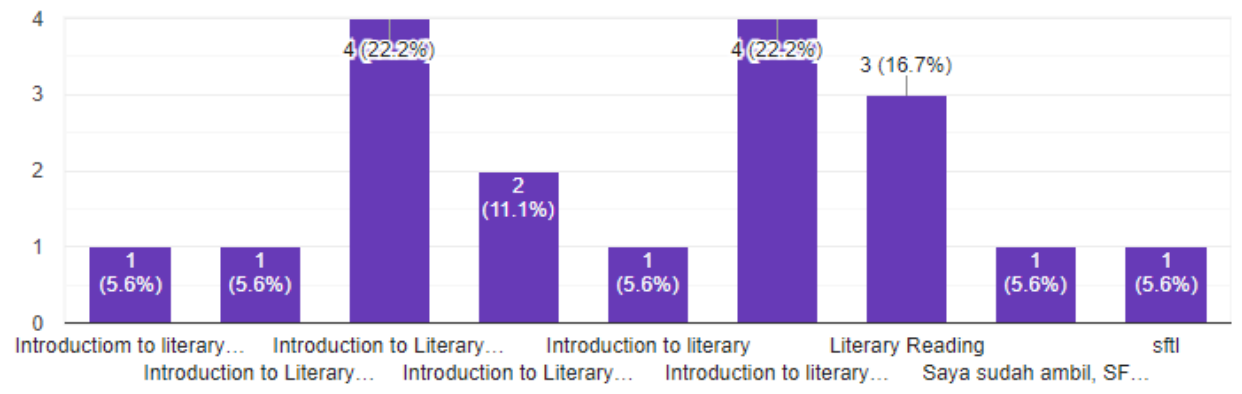

Fig. 2. Readers' experience in reading literary texts 
Based on the diagram above, $94.6 \%$ of the readers joined "Introduction to Literary Studies". In this course, they are learning to enjoy nursery rhymes and some short, simplified stories.

Some students disclosed that literary class is so difficult, boring, and always related to a very long reading. Below is the diagram of the readers' profile.

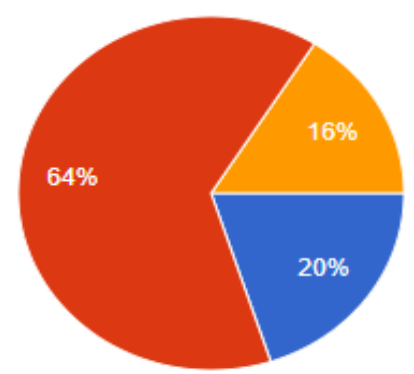

Saya adalah pembaca dengan kategori low exposure reader (tidak pernah atau hampir jarang terekspos atau membaca teks sastra)

Saya adalah pembaca dengan kategori medium exposure reader (jarang tereskspos atau kadang-kadang membaca teks sastra)

Saya adalah pembaca dengan kategori high exposure reader (sangat sering terekspos atau membaca teks sastra)

Fig. 3. Students' reading category

There are three categories of readers. They are low exposure reader picturized by the blue chart, medium exposure reader (red chart), and high exposure reader (orange chart). Based on the above diagram, the learners are categorized as low to medium exposure readers, that is, $20 \%$ and $64 \%$, respectively. Based on this data, it can be said that the readers are having less reading experience of the literary texts.

\subsection{Readers' understanding of the texts}

Most of the readers don't yet have the skills to appreciate literary texts, especially in context, giving meaning or establishing meaning for the text. Most low exposure readers focus on reading comprehension in which the readers were only retelling the story when the lecturer asked whether they could find the alternative meaning behind the texts. They said that understanding literary texts is difficult. Below is an example of students' confession regarding their difficulty.

Saya tidak menyukai membaca sastra ing karena banyak prasa dan teks yang susah di mengerti. Teks tersebut menimbulkan banyak prespektif umyang berbeda2 tiap orang yang mengakibatkan kebingungan dalam diri saya

Fig. 4. Student's testimony:

English translation of the testimony:

"I do not like English literature because there are many difficult phrases and texts. the texts cause different confusing perspectives, which is different from one person to another person leading to confusion for me".

\subsection{Readers' appreciation of the texts}


After having an understanding of the texts, the readers are encouraged to appreciate the literary texts using a reader-centered approach. Most of the readers are able to appreciate the texts better. Their responses to the texts are impressive. They are able to find alternative meaning from the texts by relating the story of the texts with their life or event with the event in their surroundings. In this case, it can be said that the text and the readers are doing an interaction in which the readers bring their knowledge to the texts, and the texts also stimulate the readers to exchange knowledge.

The application of the reader-centered approach for responding to the texts is successfully triggering the readers to appreciate the texts better by establishing meaning on their own. The following summary shows the students' performance in giving appreciation to the texts.

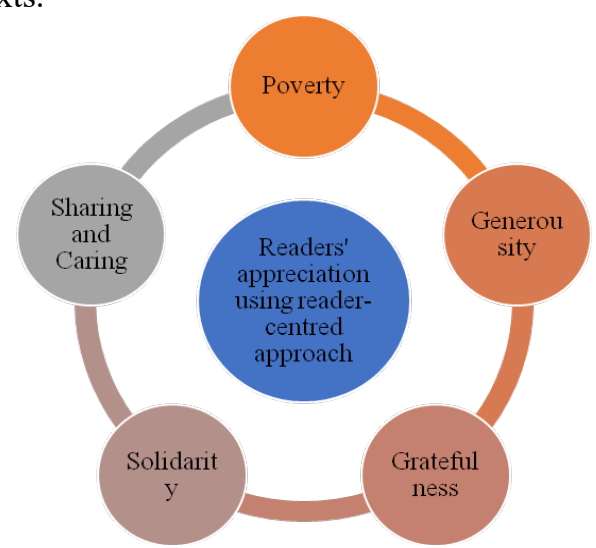

Fig. 5. Summary of readers' ideas when responding to the text entitled "Breakfast"

From the picture above, it can be said that there are at least five major ideas in readers' responses given to the text entitled "Breakfast" by John Steinbeck. They are Poverty, Generosity, Gratefulness, Solidarity, Sharing, and Caring.

"The kindness of that family amazes me. This story showed solidarity. Even though they are a poor family who had no permanent house, they were still willing to share their food with a stranger. It reminds me of the days when I was a child." (Firda, Natasya).

This also happened to the response from other read texts. Nine readers appreciated the text of the story entitled "Bullet and Rice" by Hernando R. Ocampo. In appreciating this work, some readers see it from a Poverty point of view, but some others view the work from other perspectives such as sharing and caring, the sacrifice of parents, humanity, and social classes. Readers can provide various meanings given to the text as a form of appreciation for the text. For example, readers who appreciate the point of view of humanity by stating that humans must be able to humanize other people, "From the story, I get a lesson that a human is always needed. We are human, and we must be human." (Syahid).

The third story text entitled "A True Story, Repeated Word for Word as I heard It" by Mark Twain was read by nine readers with several points of view such as Patience and Optimism, Slavery and Bullies, Tolerant, and Racism. Readers claim that they are motivated after reading the work. This indicates that the value and message conveyed through the text of the story can be delivered well to the reader, "Mark Twain wanted 
to inspire me for being a positive and optimistic person who believes the impossible thing. And he got it, I am really inspired." (Yuni Dwi).

Four readers of the text of the story entitled "Into the Storm" by Yakos Spiliotopoulos appreciated the work by expressing their opinions after reading it. The four readers have different opinions about the characterizations and the story being told. There are four opinions; namely, the work contains determination and ambition, hard work, environmental damage, and anxiety and anger. A reader analyzes the work from a hard work point of view. He believes that what Anwar did in the story is a representation of hard work, "Anwar's action in fighting the rotten government represents a "hard work" in achieving a dream. Further, if we want to reach something or our dream, we must struggle and get ready to face any risks. So Anwar did. Although he knew it was a dangerous action, he believes that he can do it well and promises to turn the whole thing around for the better." (Reza, Rafa).

Finally, the story entitled "A Tell-Tale Heart" by Edgar Allan Poe. This text is read by ten readers with various meanings. There are seven meanings resulting from the reading process of the text, namely Anxiety, Murder, Hatred, Mental Disorder, Physical Instability, and Mental Health. All of these meanings result from observations made by readers of the characters in the story. Readers feel that the main character in the story has mental disorders due to killing people and hearing things that other people do not hear. They feel that the characters in the story are experiencing severe anxiety, which causes anomalies in them. There are also those who say that it is possible that the character is influenced by the resentment within him so that he has the heart to kill someone. They also relate the story to real events that are around them, "Murder cases like this story, have happened a lot in real life. Many factors caused the killing to occur, either because of hatred, revenge, envy, hurt, and others." (Bella Sasmitha).

\section{Conclusion}

There are many challenges in understanding literary texts. This is because literary texts are written in the non-standard language, especially the selection of diction and grammar. For example, the short story written by Mark Twain entitled "A True Story, Repeated Word for Word as I Heard It" uses generative and imaginative elements in which the story presents a complex reality in another country, namely the United States. The story is told from the perspective of Misto C, a former black slave girl who works as a domestic servant in the house of a white employer. In writing the short story, Mark Twain used a diction that reflects a typical black slave-English dialect, which is very non-standard and very different from English in general.

The existence of complex generative and imaginative elements, making literary texts sometimes difficult to understand, especially for low exposure readers and medium exposure readers. Moreover, if the two types of readers do not have any allusions or references regarding the social, cultural, and historical background of slavery in the United States, it will create additional difficulties.

Through pre-reading activity, readers are given the motivation to see illustrations, videos and answer questions that lead to or are relevant to the stories that will be read in the reading process of literary texts. Hence, the reader will have an image in the head and then use it as an allusion when reading literary texts. 
The reading of literary texts uses a reader-centered approach focusing on the reader where the reader's existence is highly considered. The meaning of a text is no longer just the text that creates it but as a result of the interaction between the text and its readers. This strategy stimulates readers to be able to understand, capture, and reflect on the moral values resulting from the meaning during the reading process.

\section{References}

[1] Al-Mahrooqi, Rahma Ibrahim. (2012, January). Reading Literature in English: Challenges Facing Omani College Students. Asian EFL Journal Professional Teaching Articles, 57.

[2] Amer, Aly Anwar. Using Literature in Reading English as Second/Foreign Language. ERIC Collection ED528593, April 2012. Retrieved from https://www.researchgate.net/publication/275154728_Using_Literature_in_Reading_Engli sh_as_SecondForeign_Language/link/553407500cf2f 2 a588b2437b/download

[3] Baleiro, Rita. (2010). "Literary Literacy: Why Read Literary Texts in the English Language Classes", An e-journal of Teacher Education and Applied Language Studies (e-TEALS): 1-12. ISSN 1647-712X

[4] Fish, Stanley. (1980). Is There a Text in This Class?The Authority of Interpretive Communities. Massachusetts: Harvard University Press. diunduhdarihttp://www2.clarku.edu/ mbamberg/webcourse\%20Material/material/textinthis class.pdf

[5] Iida, Atsushi. (2013, May). Critical Review Of Literary Reading and Writing in a Second Language. The Journal of Literature in Language Teaching, 2. ISSN: 2187-722X

[6] Iser, Wolfgang. (1974). The Reading Process a Phenomenological Approach. Baltimore: John Hopkins University Press. Retrieved from https://pdfs.semanticscholar.org/1ff3/44f7c70916e6b94fb3e886f20898f8c24f3e.pdf?_ga=2. 261462157.1634253217.1586029892-1932651208.1585582644

[7] Kuijpers, Moniek M. \& Hakemulder, Frank. (2018). Understanding and Appreciating Literary Texts Through Rereading. Discourse Processes, 55(7), 619-641, DOI: 10.1080/0163853X.2017.1390352

[8] Mart, Cagri Tugrul. (2019, July). Reader-Response Theory and Literature Discussions: A Springboard

for Exploring Literary Text, The New Educational Review. DOI: $10.15804 /$ tner.2019.56.2.06

[9] Novianti, Nita. (2016, July). English Literature Teaching: An Indonesian Context. Indonesian $\begin{array}{lllll}\text { Journal of Applied Linguistics (IJAL), 6(1), 42-49. } & \text {. }\end{array}$ Diunduhdarihttps://ejournal.upi.edu/index.php/IJAL/article/view/2660/1869

[10] Rosenblatt, Louise M. (2007). Writing and Reading: The Transactional Theory. Illinois: University of Illinois at Urbana-Champaign. Diunduhdarihttps://www.ideals.illinois.edu/bitstream/handle/2142/18044/ctrstreadtechrepv 01988i00416_opt.pdf

[11] Sanchez, Hugo S. (2009). Building up literary reading responses in foreign language classrooms. English Language Teacher Education and Development, 12, 01-13. 